\title{
The Communication Efforts to Build New Normal Era Tourism Awareness by the Indonesian Ministry of Tourism and Creative Economy through the Media
}

\author{
H. A. Nova ${ }^{1}$, A.N. Rahmanto ${ }^{2}$, Sudarmo ${ }^{3}$ \\ ${ }^{1}$ Master of Communication Study Program of Faculty of Social and Political Sciences of Sebelas Maret \\ University, Surakarta, Indonesia, ${ }^{2,3}$ Faculty of Social and Political Sciences of Sebelas Maret University, \\ Surakarta, Indonesia \\ 1hikmawankp@gmail.com, ${ }^{2}$ andre@staff.uns.ac.id, ${ }^{3}$ sudarmo63@yahoo.com
}

\begin{abstract}
The efforts to rebuild tourism sectors in Indonesia destroyed by the arrival of the 2019 / Covid-19 corona virus disease novel pandemic since March 2020, include through communication of the implementation of special health protection protocols in the tourism and economic sectors driven by the Ministry of Tourism and Creative Economy/Kemenparekraf RI. The importance of communication efforts is carried out to build public awareness and industry players about tourism in the new normal era so that it is expected to stimulate tourism in the region, the positive implications of which can be felt through the wheels of the economy of the community around tourist destinations and ultimately sustainable tourism development can continue to be implemented. The communication efforts undertaken by Kemenparekraf include through a press release, which is distributed by the mass media so that it can be widely distributed in the public. This study uses the media framing theory and examines the use of press releases issued by the Ministry of Tourism and Creative Economy in June-July 2020, so that it can explain the communication efforts undertaken to build awareness of the Indonesian people about tourism during the pandemic.
\end{abstract}

Keywords: covid-19, framing theory, communication, media, press release.

\section{Introduction}

The pandemic novel corona virus disease 2019 / Covid-19 in Indonesia was officially present on 2 March 2020 when it was announced by the President of the Republic of Indonesia Joko Widodo at the State Palace in Jakarta with two people being the first sufferers [1]. Since then, the number of positive sufferers has continued to rise and based on the official government website related to Covid-19 information, namely www.covid19.go.id, until 27 July 2020 the number has reached 100.303 positive patients, with 58.173 patients recovering, and 4.838 patients died [2]. This figure is in fact a sign of economic collapse in the community, and directly Covid-19 has a very big impact in terms of health, economic, social, and cultural. Tourism, which has become one of the largest contributors to the country's foreign exchange earner, labor producers, and is closely linked to sustainable development goals, is the most affected sector. Data shows that in 2019 the tourism sector succeeded in bringing in foreign exchange of 280 trillion, attracting 16 million foreign tourists, contributing to the national GDP of 5,5\%, and absorbing a workforce of 13 million [3]. Since the Covid-19 pandemic came to Indonesia, the impact of the tourism sector has been felt since the international world to restrict flights in early 2020, the tourism sector has declined 
dramatically where the arrival of foreign tourists in February and March 2020 based on data from BPS for February 2020 only there were 864 thousand people coming to Indonesia compared to 1,24 million people in February 2019 and in March 2020 there were 470 thousand foreign tourists compared to 1,31 million in March 2019, or in conclusion the foreign tourist arrivals in January-March 2020 fell by 30,62\% compared to January-March 2019 [4].

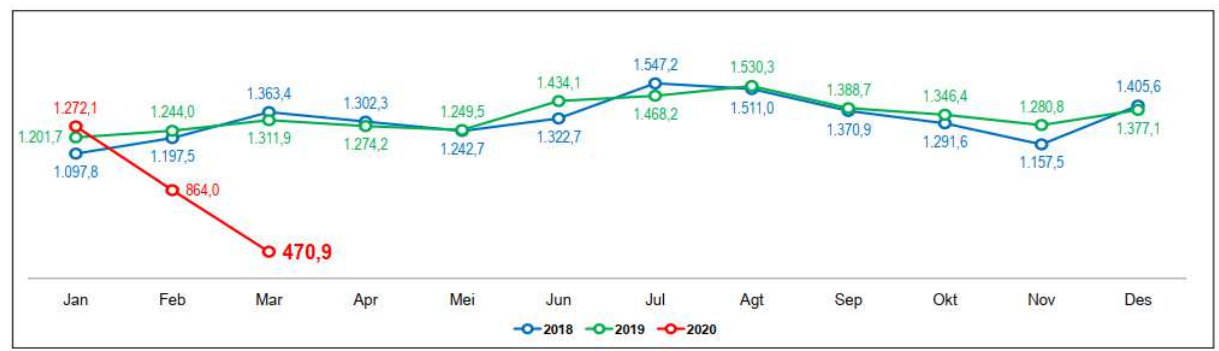

Fig.1. The Graph of foreign tourists visiting Indonesia Source: Bappenas RI, 2020

In addition, the immediate impact felt by the community is on tourism-related jobs such as travel services, travel and public transportation drivers, accommodation services, culinary, recreation areas, shopping centers and small and medium-sized businesses related to tourism. These perceived impacts require a response from the Government of Indonesia, which is now entering a new normal era that requires people to live with strict health protocols.

The Government of the Republic of Indonesia through the Ministry of Health issued a policy on implementing health protocols specifically for the tourism sector and the creative economy compiled by the Ministry of Tourism and Creative Economy (Kemenparekraf) together with relevant stakeholders on 22 June 2020 [5]. With the presence of the policy, one of the heavy tasks is to carry out the communication efforts in building awareness from the public and industry players about tourism in the new normal era by using health protocols so that it is expected to be able to re-stimulate tourism in various regions, the positive implications of which can be felt through the wheels of the economy communities around tourist destinations and ultimately sustainable tourism development can continue. One of the efforts of Kemenparekraf to communicate various programs and policies is through making official press releases to then be disseminated through mass media and social media both internal and external.

There were 95 press releases officially released by the Kemenparekraf at intervals from 22 June 2020 (since the special health protocol in the tourism sector and the creative economy was inaugurated) until 27 July 2020, and researchers analyzed the use of new normal era tourism themes and their application by the public and actors the tourism industry, so that it is expected to know the communication efforts made to build awareness of the Indonesian people about tourism in the pandemic by Kemenparekraf. The use of press releases is investigated because of its important function as a liaison with the public and the media, where press releases are a form of proactive communication to the public expressed by S. Grimmelikhuijsen, F.D. Vries, and W. Zijlstra in 2018 [6] and a tool to imply social meaning by choosing the right words so that they can maintain healthy relations with the public by Ling in 2017 [7]. In addition, according to Morton \& Ramsey (1994) press releases are useful for publishing information from an organization, especially information that impacts or appeals to 
large groups of people [8]. The importance of analyzing the press release is also due to the current function according to Gilpin (2008) which has become broader than just a means of communication with the public into the formation of organizational identity in the public eye through narrative efforts regarding events and organizational functions [9].

The problem in this research is the need to build public awareness of compliance with health protocols that are specifically applied to the tourism sector and the creative economy, which requires massive dissemination of information, especially from the government as a regulator. From this problem, then examined the steps taken by the government, in this case is Kemenparekraf, to disseminate information through the media whose channels were originally made in the form of press releases with content about health protocols specifically for the tourism sector and the creative economy.

\section{Method}

This study uses descriptive qualitative methods and media framing theory to analyze the use of press releases by Kemenparekraf RI located on the https://pedulicovid19.kemenparekraf.go.id/category/info-parekraf/siaran-pers/ on June 22, 2020 ( since the special health protocol for the tourism sector and the creative economy was formalized) until July 27, 2020. According to H. Nawawi \& M. Martini (1994), descriptive methods describe an objective situation and are based on real or actual facts, and then general conclusions based on this fact [10]. Media framing theory is used to understand framing and the purpose of publishing press releases by Kemenparekraf RI, where according to Littlejohn (2017) framing refers to the process of uniting news or other types of media messages, including the ways in which the news is organized and the organization sending cues about how to understand the content discussed [11]. A. Tversky \& D. Kahneman (1992) uses prospect theory, which is a development of framing theory, to illustrate how message framing can influence decision making in uncertain conditions [12]. Research on media framing and press releases has been carried out includes by J. Choi \& S. Lee (2017) regarding framing analysis on press releases related to the crisis of the Fukushima nuclear power plant [13]; and S. Grimmelikhuijsen, F.D. Vries, and W. Zijlstra (2018) regarding the effects of press releases and media coverage on the perception of trust [14]; and by Lee \& Basnyat (2013) regarding framing mapping during the H1N1 influenza pandemic [15].

The data used are primary data taken from the official press release of the Republic of Indonesia Ministry of Tourism and Creative Economy, with secondary data derived from analytical observations from books, scientific journals, research reports, presentation materials from official government agencies, and other related data.

\section{Result And Discussion}

The impact caused by the pandemic novel corona virus disease 2019 / Covid-19 in the tourism sector was felt directly by the public, and the drastic reduction in the number of foreign tourist arrivals to Indonesia resulted in the decline in foreign exchange generated by the tourism sector. After undergoing a pandemic for five months, currently in Indonesia has entered a new normal era that also applies to the tourism sector and its supporters by implementing special health protocols in the tourism sector and creative economy which 
among others are applied to tourist destinations/recreation areas, shopping centers, and culinary place. With good communication efforts, awareness of traveling by following the protocol will occur and it is hoped that tourist destinations and tourism businesses will continue to run, and therefore efforts are needed from policy makers, in this case Kemenparekraf RI. In general, the impact of Covid-19 on tourism does not only occur in Indonesia but also the world. In various countries, there has been a decrease in the level of foreign tourist arrivals, flight restrictions and foreign arrivals, tightening of tourism sector regulations, and creating new strategies to bring in tourists (as in the table below) [16].

Table 1. Impact of Covid-19 on tourism

\begin{tabular}{|c|c|c|c|}
\hline & Q1 2020 & Q2 2020 (up to April 2020) & $\begin{array}{c}\text { Q3 \& Q4 } 2020 \\
\text { (Prediction and Development) }\end{array}$ \\
\hline$\sum_{\substack{0 \\
0 \\
0}}$ & $\begin{array}{l}\text { The arrival of foreign } \\
\text { tourists in several countries } \\
\text { (Singapore, Thailand, } \\
\text { Japan, South Korea, } \\
\text { Vietnam, Hong Kong) fell } \\
\text { between } 70-90 \%\end{array}$ & $\begin{array}{l}\text { - China is starting to recover } \\
\text { Thailand in June opened } 2 \text { islands for tourists (Koh } \\
\text { Samui and Koh Pangan) with the tagline luxury tourism } \\
\text { Vietnam has begun to open gradually independent } \\
\text { digitally driven traveler } \\
\text { Australia and Singapore discuss the concept of travel } \\
\text { bubbles or special tourism corridors in the green zone } \\
\text { countries }\end{array}$ & $\begin{array}{c}\text { Flight occupancy has declined } \\
\text { because of restrictions and the } \\
\text { courage to travel has not yet } \\
\text { recovered }\end{array}$ \\
\hline 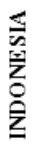 & $\begin{array}{l}\text { The arrival of foreign } \\
\text { tourists in Indonesia fell in } \\
\text { the range of } 70 \%\end{array}$ & $\begin{array}{l}\text { The arrival of foreign tourists in Indonesia fell in the range } \\
\text { of } 90 \%\end{array}$ & $\begin{array}{c}\text { Some international events have } \\
\text { not yet confirmed the } \\
\text { cancellation, especially in Bali }\end{array}$ \\
\hline
\end{tabular}

Source: Badan Pelaksana Otorita Danau Toba, 2020

The Ministry of National Development Planning of the Republic of Indonesia / National Development Planning Agency (Bappenas) points out that the two sectors of tourism in Indonesia that were most seriously affected due to Covid-19 are accommodation providers where negative impacts occur due to a decrease in the number of foreign and domestic tourist visits, as well as restrictions the movement of the community so that restaurants can only do delivery or take away as well as transportation providers with the largest decrease in air transport, while the decline in freight activity is restrained by increasing online shopping shipments in line with work from home policies [17]. In addition Kemenparekraf RI estimates that the Covid-19 pandemic could result in Indonesia losing foreign exchange from the tourism sector by $50 \%$ or 140 trillion rupiahs, for which the 2020 target has an initial projection of 280 trillion rupiahs of foreign exchange [18].

In addition, Bappenas explained that the impact of Covid-19 on the tourism sector consisted of five points, which occurred in the hotel sector, travel and transportation services, the food and beverage industry, the cinema, and tourism and MICE activities (meetings, incentives, conventions, exhibitions) and There are four risks that must be faced (see the table below) [19]: 
Table 2. Impact and risk of Covid-19 on the Indonesian tourism industry

\begin{tabular}{|c|c|}
\hline Impact of Decline & Risk \\
\hline 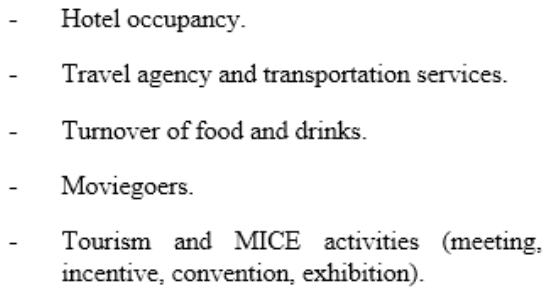 & $\begin{array}{l}\text { - } \quad \text { Temporary hotel and restaurant closures. } \\
\text { - } \quad \begin{array}{l}\text { Reduction of employees / termination of } \\
\text { employment. }\end{array} \\
\text { - } \quad \begin{array}{l}\text { Failed to pay for investment loans and } \\
\text { working capital loans. }\end{array} \\
\text { - Permanent closure of business. }\end{array}$ \\
\hline
\end{tabular}

Source: Bappenas RI, 2020

The government has responded to various impacts, in this case the authority is the Ministry of Tourism and Creative Economy, which divides the three conditions of the Covid-19 pandemic into three parts, namely emergency response conditions, adaptation conditions, and recovery conditions [20]:

Table 3. Distribution of conditions for the impact of Covid-19 on tourism in Indonesia

\begin{tabular}{|c|c|c|}
\hline $\begin{array}{l}\text { Covid-19 Emergency Response } \\
\text { Conditions }\end{array}$ & Adaptation Conditions & Recovery Conditions \\
\hline $\begin{array}{l}\text { Tourist attractions, shopping, } \\
\text { and entertainment during the } \\
\text { PSBB. } \\
\text { Declining domestic market } \\
\text { demand and purchasing } \\
\text { power. }\end{array}$ & $\begin{array}{l}\text { - Formulation of a new normal } \\
\text { adaptation for tourism and the } \\
\text { tourism industry. } \\
\text { Formulation of Clean, Health, and } \\
\text { Safety in Implementation in the } \\
\text { Tourism Industry. }\end{array}$ & $\begin{array}{l}\text { - } \quad \text { Easing PSBB. } \\
\text { - Implementation of Cleanliness, } \\
\text { Health \& Safety Procedures in the } \\
\text { parekraf sector. } \\
\text { - }\end{array}$ \\
\hline
\end{tabular}

Source: Kemenparekraf RI, 2020

After mapping out these three types of conditions, there are various policies to address the impact of the Covid-19 pandemic on tourism in Indonesia, which is divided into two stages, the Covid-19 emergency response program and the recovery phase program[21]:

Table 4. Covid-19 prevention program in the Indonesian tourism sector

\begin{tabular}{|c|c|}
\hline Covid-19 Emergency Response Phase Program (Outbreak) & Recovery Phase Program (Recovery) \\
\hline 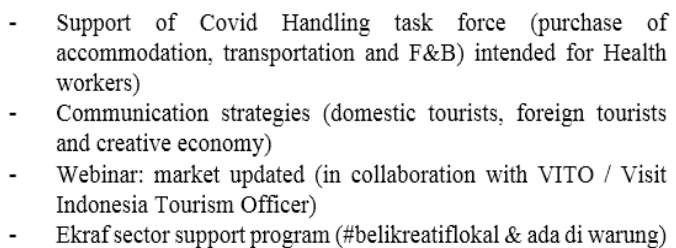 & $\begin{array}{l}\text { - Kemenparekraf's strategic campaigns \& movements: } \\
\text { Cleanliness, health, safety procedures; } \\
\text { \#belikreatiflokal; and \#diindonesiaaja. } \\
\text { Aiming to increase public, domestic and international } \\
\text { trust in Indonesian tourism and improve the economic } \\
\text { capabilities of the parekraf sector in Indonesia and } \\
\text { GDP indirectly. }\end{array}$ \\
\hline
\end{tabular}

Source: Kemenparekraf RI, 2020

Various programs at the above stage have been running, and the government has decided to open a tourist destination with a health protocol. This decision should be properly socialized and publicized, especially through the Communication Bureau section of the Kemenparekraf organization. Based on the Regulation of the Minister of Tourism and Creative Economy / 
Head of the Tourism and Creative Economy Agency of the Republic of Indonesia Number 1 Year 2020 concerning the Organization and Work Procedure of the Ministry of Tourism and Creative Economy / Head of the Tourism and Creative Economy Agency, the Communication Bureau has the task of carrying out guidance and providing public information support, public relations, digital media management, and content production within the Ministry / Agency, as well as having the function of preparing guidance and providing support in the field of public information, implementing public relations, implementing digital media management, and implementing content production [22]. One of the channels to publish policies regarding the implementation of special health protocols in the tourism sector and the creative economy by Kemenparekraf is through a press release that is routinely issued on the official website https://pedulicovid19.kemenparekraf.go.id/category/info-parekraf/siaran-pers/.

Health protocols, which focuses on three main issues (hygiene, health, and safety), is issued by the government and can serve as a guide for interested stakeholders, visitors and the community and apply to the tourism industry such as hotel, restaurants, tourist attractions, modes of transportation, creative economic and event / meeting organizer services, as well as places and facilities that are closely related to the tourism sector and the creative economy.

There are 95 official Kemenparekraf press releases issued from 22 June 2020 to 27 July, and it can be analyzed that in general there are two main tasks and functions of Kemenparekraf namely tourism and creative economy which are the contents of the press release, as well as content that includes both basic tasks and functions. The percentage comparison of the number of press releases with the three types of content is as follows:

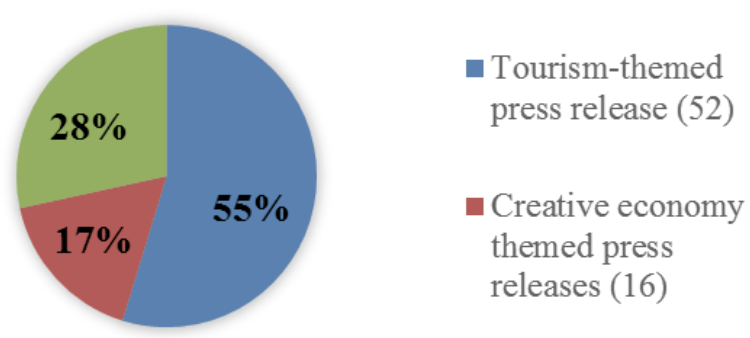

Fig.2. Percentage of official press releases by Kemenparekraf RI Source: Processed from Kemenparekraf website, 2020

From a tourism-themed press release, the researchers divided the content into two parts, namely content specifically discussing the application of special health protocols in the tourism sector and other tourism content. Based on the analysis, the percentage of distribution is as follows:
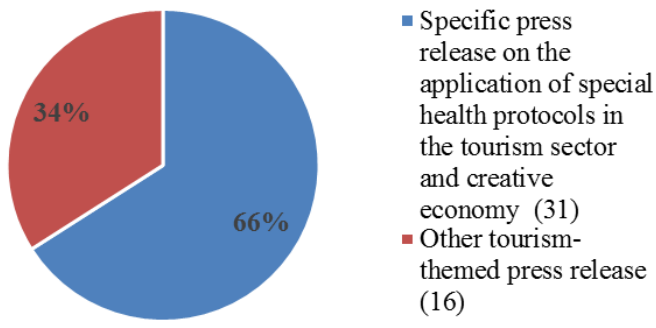

Fig.3. Percentage of official press releases by Kemenparekraf RI 2 Source: Source: Processed from Kemenparekraf website, 2020 
The following is the title of the press release specifically made with content regarding health protocols specific to the tourism sector and the creative economy:

Table 5. Recapitulation of the Kemenparekraf RI Press Release with specific content

\begin{tabular}{|c|c|c|c|c|c|}
\hline No & Date & Press Release Title & No & Date & Press Release Title \\
\hline 1 & 22 June & $\begin{array}{l}\text { Pemerintah Resmi Sahkan Protokol Kesehatan } \\
\text { Sektor Pariwisata dan Ekonomi Kreatif }\end{array}$ & 17 & 16 July & $\begin{array}{l}\text { Kemenparekraf: Disiplin Protokol Kesehatan } \\
\text { Jadi Kunci Kebangkitan Sektor Pariwisata }\end{array}$ \\
\hline 2 & 24 June & $\begin{array}{l}\text { Kemenparekraf Ingatkan Pentingnya Protokol } \\
\text { Kesehatan dalam Rencana Pembukaan } \\
\text { Destinasi }\end{array}$ & 18 & 17 July & $\begin{array}{l}\text { Kemenparekraf Lengkapi Fasilitas Destinasi } \\
\text { Wisata di Bali Melalui "Bali Rebound" }\end{array}$ \\
\hline 3 & 28 June & $\begin{array}{l}\text { Mengembalikan Kepercayaan Wisatawan Jadi } \\
\text { Kunci Sukses Pemulihan Seltor Pariwisata }\end{array}$ & 19 & 18 July & $\begin{array}{l}\text { Kemenparekraf Dukung "Mandalika } \\
\text { Rebound" Pulihkan Pariwisata NTB di Era } \\
\text { Normal Baru }\end{array}$ \\
\hline 4 & 29 June & $\begin{array}{l}\text { Kemenparekraf Pantau Penerapan Protokol } \\
\text { Kesehatan di Destinasi }\end{array}$ & 20 & 19 July & $\begin{array}{l}\text { Kemenparekraf Dukung Pariwisata } \\
\text { Yogyakarta Masuki Adaptasi Kebiasaan } \\
\text { Baru Melalui Gerakan BISA }\end{array}$ \\
\hline 5 & 2 July & $\begin{array}{l}\text { Pengelola Candi Prambanan dan Ratu Boko } \\
\text { Berlakukan Protokol Ketat dalam Uji Coba } \\
\text { Pembukaan }\end{array}$ & 21 & 19 July & $\begin{array}{l}\text { Kemenparekraf Gulirkan Gerakan BISA di } \\
\text { Sejumlah Destinasi Kepulauan Riau }\end{array}$ \\
\hline 6 & 2 July & $\begin{array}{l}\text { TN Komodo Terapkan Sistem Registrasi } \\
\text { Online bagi Wisatawan saat Normal Baru }\end{array}$ & 22 & 19 July & $\begin{array}{l}\text { Kemenparekraf Masyarakatkan CHSE di } \\
\text { Destinasi Wisata NTB Melalui Gerakan } \\
\text { BISA }\end{array}$ \\
\hline 7 & 6 July & $\begin{array}{l}\text { Kemenparekraf Libatkan } 20 \text { Desa Wisata Ikut } \\
\text { Gerakan BISA di Magelang }\end{array}$ & 23 & 21 July & $\begin{array}{l}\text { Pelaku Wisata Harus Siap Terapkan Protokol } \\
\text { Kesehatan di Era Kebiasaan Baru }\end{array}$ \\
\hline 8 & 6 July & $\begin{array}{l}\text { Menparekraf Imbau Restoran di Destinasi } \\
\text { Wisata Disiplin Terapkan Protokol Kesehatan }\end{array}$ & 24 & 22 July & $\begin{array}{l}\text { Kemenparekraf Gelar Gerakan BISA dan } \\
\text { BALASA di Kabupaten Bandung Jabar }\end{array}$ \\
\hline 9 & 7 July & $\begin{array}{l}\text { Tingkatkan Kepercayaan Wisatawan, } \\
\text { Kemenparekraf Sosialisasi Protokol } \\
\text { Kesehatan }\end{array}$ & 25 & 23 July & $\begin{array}{l}\text { Kemenparekraf Gelar Gerakan BISA di } \\
\text { Pantai Depok Pekalongan }\end{array}$ \\
\hline 10 & 9 July & $\begin{array}{l}\text { Menparelcraf Tekankan Hotel-Restoran } \\
\text { Disiplin Protokol Kesehatan Agar Tetap } \\
\text { Produktif dan Aman }\end{array}$ & 26 & 23 July & $\begin{array}{l}\text { Terapkan Protokol Kesehatan Dengan Benar } \\
\text { Kunci Utama Adaptasi Kebiasaan Baru }\end{array}$ \\
\hline 11 & 9 July & $\begin{array}{l}\text { Kemenparekraf Segera Terbitkan Buku } \\
\text { Panduan Protokol Kesehatan Usaha Parekraf }\end{array}$ & 27 & 23 July & $\begin{array}{l}\text { Likupang Rebound Bangkitkan Semangat } \\
\text { Masyarakat Hadirkan Destinasi yang Bersih, } \\
\text { Indah, Sehat, dan Aman }\end{array}$ \\
\hline 12 & 11 July & $\begin{array}{l}\text { Menparekraf Pastikan Penerapan Protokol } \\
\text { Kesehatan di Bioskop Berjalan Baik }\end{array}$ & 28 & 24 July & $\begin{array}{l}\text { Kemenparekraf Ajak Warga Bunaken Selalu } \\
\text { Disiplin Terapkan Protokol Kesehatan }\end{array}$ \\
\hline 13 & 12 July & $\begin{array}{l}\text { Normal Baru di Candi Borobudur dan Ratu } \\
\text { Boko }\end{array}$ & 29 & 24 July & $\begin{array}{l}\text { Kemenparekraf Ajak Masyarakat Tegal Ikut } \\
\text { Gerakan BISA Pulihkan Sektor Pariwisata }\end{array}$ \\
\hline 14 & 13 July & $\begin{array}{l}\text { Kemenparekraf Dorong Pengusaha Hotel dan } \\
\text { Restoran Terapkan Protokol Kesehatan }\end{array}$ & 30 & 25 July & $\begin{array}{l}\text { Menparekraf Ajak Generasi Muda Jadi Agen } \\
\text { Perubahan di Era Adaptasi Kebiasaan Baru }\end{array}$ \\
\hline 15 & 14 July & $\begin{array}{l}\text { Kemenparekraf Terbitkan Buku Panduan } \\
\text { Protokol Kesehatan di Bidang Hotel dan } \\
\text { Restoran }\end{array}$ & 31 & 27 July & $\begin{array}{l}\text { Kemenparekraf Gelar Program Padat Karya } \\
\text { "BISA" di Sejumlah Desa Wisata NTB }\end{array}$ \\
\hline 16 & 14 July & $\begin{array}{l}\text { Menparekraf Apresiasi Terbitnya Buku } \\
\text { Panduan Protokol Kesehatan Pelayanan } \\
\text { Makanan Minuman }\end{array}$ & & & \\
\hline
\end{tabular}

Source: Processed from Kemenparekraf website, 2020

From the table above, there are four discussion points, namely: 1) Regarding the health protocol regulations in the tourism sector and the creative economy; 2) Readiness to apply health protocols to tourist destinations and other tourism industries and their urgency; 3) Implementation of programs that refer to health protocols (through the BISA Movement and Rebound Destinations); 4) Appeal to implement health protocols.

Essential finding in this research is when viewed from the overall percentage, the content regarding the application of health protocol specifically for the tourism sector, amounting to 31 press releases has a percentage of $33 \%$ of the total press release, and seeing the duties and 
functions of Kemenparekraf in handling the tourism sector and the creative economy, the researchers consider this amount to be sufficient, although in terms of frequency and continuity it still needs to be increased because to be able to build awareness and influence the community, a continuous and sustainable effort with themes and content is needed.

\section{Conclusions}

The tourism sector in Indonesia, which is one of the sectors most affected by the existence of the Covid-19 pandemic, requires efforts from various parties to rise and re-develop. The magnitude of the influence of the sector is reflected in the realization of the foreign tourist arrivals fell as well as the loss of people's livelihoods so that it had a serious impact on the economic situation in Indonesia. Various policies presented by Kemenparekraf RI are communication efforts to build public awareness and the tourism industry in the new normal era through press releases with specific, targeted, and continuous content, so that the ultimate goal of these efforts can be achieved because of the preparation of opening tourist destinations and other tourism industries urgently need the implementation of strict health protocols so that the efforts made do not turn around and cause negative impacts from the presence of the Covid-19 pandemic which is still very vulnerable.

\section{References}

[1] "Fakta Lengkap Kasus Pertama Virus Corona di Indonesia," https://nasional.kompas.com/read/2020/03/03/06314981/fakta-lengkap-kasus-pertama-viruscorona-di-indonesia accessed on 28 July 2020, 2020.

[2] "Peta Sebaran Kasus Covid-19 di Indonesia," https://covid19.go.id/peta-sebaran accessed on 28 July 2020, 2020.

[3] "Sepanjang 2019, devisa sektor pariwisata mencapai Rp 280 triliun," https://nasional.kontan.co.id/news/sepanjang-2019-devisa-sektor-pariwisata-mencapai-rp-280triliun accessed on 28 July 2020, 2020.

[4] KPPN/Bappenas RI, "Tantangan dan Peluang Pariwisata: Tourism After Covid-19," Presentation on Kuliah Umum Komunikasi Pemasaran Pariwisata - Pariwisata NTB Menuju New Normal 12 May 2020, 2020.

[5] "Pemerintah Resmi Sahkan Protokol Kesehatan Sektor Pariwisata dan Ekonomi Kreatif," https://pedulicovid19.kemenparekraf.go.id/siaran-pers-pemerintah-resmi-sahkan-protokolkesehatan-sektor-pariwisata-dan-ekonomi-kreatif/ accessed on 28 July 2020, 2020.

[6] S. Grimmelikhuijsen, F. d. Vries \& W. Zijlstra, "Breaking bad news without breaking trust: The effects of a press release and newspaper coverage on perceived trustworthiness," Journal of Behavioral Public Administration, Vol 1(1), pp. 1-10, 2018.

[7] M. Ling, Press Release: A Tool for Public Relations, in Banking: Services, Opportunities and Risks, New York: Nova Science Publishers, 2017.

[8] L. P. Morton \& S. Ramsey, "A benchmark study of the PR news wire," Public Relations Review, 20(2), 171-182, 1994.

[9] D. R. Gilpin, "Narrating the organizational self: Reframing the role of the news release," Public Relations Review 34 (2008) 9-18, 2008.

[10] H. Nawawi \& M. Martini, Penelitian Terapan, Yogyakarta: Gajahmada University Press, 1994.

[11] S.W. Littlejohn, K.A. Foss \& J.G. Oetzel, Theories of Human Communication (11th ed.), Illinois: Waveland Press, 2017. 
[12] A. Tversky \& D. Kahnemann, "Advanced in Prospect Theory: Cumulative Representation of Uncertainty," Journal of Risk and Uncertainty 5 297-323, 1992.

[13] J. Choi \& S. Lee, "Managing a crisis: A framing analysis of press releases dealing with the Fukushima nuclear power station crisis," Public Relations Review, 2017.

[14] S. Grimmelikhuijsen, F. D. Vries \& W. Zijlstra, "Breaking bad news without breaking trust: The effects of a press release and newspaper coverage on perceived trustworthiness," Journal of Behavioral Public Administration, Vol 1(1), pp. 1-10, 2018.

[15] S.T. Lee \& I. Basnyat, "From Press Release to News: Mapping the Framing of the 2009 H1N1 A Influenza Pandemic," Health Communication, 28:2, 119-132, 2013.

[16] Badan Pelaksana Otorita Danau Toba, "Pariwisata dan Adaptasi Tatanan Baru Destinasi Pariwisata Super Prioritas Danau Toba", Presentation on Webinar Pariwisata dan Adaptasi Tatanan Baru Genpinas 19 June 2020, 2020.

[17] KPPN/Bappenas RI, "Tantangan dan Peluang Pariwisata: Tourism After Covid-19," Presentation on Kuliah Umum Komunikasi Pemasaran Pariwisata - Pariwisata NTB Menuju New Normal 12 May 2020, 2020.

[18] “3 Bulan Dihantam Corona, Pariwisata RI Rugi Rp 140 Triliun,” https://travel.detik.com/travelnews/d-4985043/3-bulan-dihantam-corona-pariwisata-ri-rugi-rp-140-triliun accessed on 28 July 2020, 2020.

[19] KPPN/Bappenas RI, "Tantangan dan Peluang Pariwisata: Tourism After Covid-19," Presentation on Kuliah Umum Komunikasi Pemasaran Pariwisata - Pariwisata NTB Menuju New Normal 12 Mei 2020, 2020.

[20] Kemenparekraf RI, "Pariwisata \& Adaptasi Kenormalan Baru," Presentation on Webinar Pariwisata dan Adaptasi Tatanan Baru Genpinas 19 Juni 2020, 2020.

[21] Kemenparekraf RI, "Pariwisata \& Adaptasi Kenormalan Baru," Presentation on Webinar Pariwisata dan Adaptasi Tatanan Baru Genpinas 19 Juni 2020, 2020.

[22] Kemenparekraf RI, "Peraturan Menteri Pariwisata dan Ekonomi Kreatif/Kepala Badan Pariwisata dan Ekonomi Kreatif Republik Indonesia Nomor 1 Tahun 2020 tentang Organisasi dan Tata Kerja Kementerian Pariwisata dan Ekonomi Kreatif/Kepala Badan Pariwisata dan Ekonomi Kreatif,” Jakarta, 2020. 